\title{
METHODOLOGICAL ASPECTS OF QUANTITATIVE ASSESSMENT OF THE POLLUTION REDUCTION - STATUS AND TREND -
}

\author{
Viktor Voytsekhovskyy \\ Bukovynsky University, Chernivtsy, Ukraine \\ Viktoriya Voytsekhovska \\ Lviv Polytechnic National University, Lviv, Ukraine
}

(c) MESTE NGO

JEL Classification: Q52, Q53

\begin{abstract}
The methodology of analytical approach is based on establishing the parameters that characterize the essence of the developed phenomenon. The state of air pollution in particular is seen as the main factor that significantly affects the residents' livelihoods. At one and the same degree of negative pollution, its effect will depend on the number of residents living in the area. Therefore, for the assessment of air pollution reduction state, the two indicators were developed - harmful gas components in the air and population density in the area. Based on the hypothesis of parabolic type, the corresponding functional relation between the parameters proves, that the product of assumed parameters determines the priority of pollution reduction in some areas. To the upgrade option of renewed system equipment in order reduce contamination, we propose to use appropriate quantitative relations. They can determine the dynamics of pollution, depending on the innovative coefficient for pollution factors and investments in new equipment. Also, the dependence to assess pollution abatement in the implementation of multistage treatment systems is given. The conducted proposed approach to interpretation of dust pollution on the example of region of Poland is developed.
\end{abstract}

Keywords: Environmental pollution, Voivodships, industrial gas pollutans, investments

\section{INTRODUCTION}

In accordance with the European Environment Agency Air Quality in Europe report of 2013,

Address of the corresponding author: Viktor Voytsekhovskyy 害” viktor.voytsekhovskyy@gmail.com
'There are still major challenges to human health from poor air quality. We are still far from our objective to achieve levels of air quality that do not give rise to significant negative impacts on human health and the environment.' Janez Potočnik, European Commissioner for the Environment (EEA, 2013).

This means, that environmental security remains very actual topic in Europe and worldwide. 
As it is stressed by United Nations Sustainable Development programme, the global partnership for development is crucial for international wellbeing and Millenium Development Goals implementation, however the economic policies of each country and region is on its own responsibility, and the regional sustainable is highly important here (U.N., The future we want, 2012).

At the same time, during Follow up international conferemce in Doha, Quatar of the United Nations stresses, that national development efforts need to be supported by an enabling international economic environment (U.N., Doha Declaration on Financing for Development: outcome document of the Follow-up International Conference on Financing for Development to Review the Implementation of Monterrey Consensus, 2008).

\section{THE CONCEPT}

The option of gas emissions that affects people is being considered. An important factor in favor concentration of harmful elements and the air. Equivalent to a certain extent characteristic of concentration is considered to be corresponding:

$d=\frac{\mathrm{z}}{\mathrm{s}}$,

where:

$$
\begin{aligned}
& Z \text { - emissions into environment, } \\
& \mathrm{S} \text { - emissions area. }
\end{aligned}
$$

With the increase of the negative component in the air, which is consumed in the process of human life, we should expect more significant damage to the human body at the same conditions. While analyzing the impact of pollution on humans there, the problem of identifying the quantitative relations between causes and consequences arises. In general the definition of the relevant laws requires a special complex and long-term research with specialists in various industries. At the same time to solve a number of practical problems is sufficient to approximate approaches that allow to take real effective solutions, in particular, on the basis of logical reasoning.
From the standpoint of selecting analytical interrelationships between factors we offer to focus on the Powers features the following:

$e=c d^{2}$,

where:

$e$ - negative impact from the consequences of environmental pollution per capita,

$c$ - constant coefficient.

This dependence is characterized by the fact that, firstly, in the absence of pollution there will be no negative consequences, that is consistent with logical reasoning. Secondly, there is non-linearity effects of pollution. This means that one and the same absolute reduction of pollution for its various levels leads to unequal results of its influence. For higher limits overall pollution effect of the measures to reduce it to grow. General idea for the pollution reduction priority in areas with high gas emissions concentrations should be considered quite reasonable and this approach is often used in the practice of management.

Lets assume, that on the certain territory $\mathrm{N}$ people are living, then the dependence (2) can be modified as follows:

$E=N c d^{2}$

By using the derivative apparatus for elementary functions that determine the quantitative relation between changes in pollution and its effect:

$\Delta E=2 c d v \Delta Z$

where $\mathrm{v}$ - population density in the area of contamination.

As can be seen from the dependence (4), the assumptions taken overall effect of the pollution is caused by changes in the product of two factors - pollution concentrations and density of the population living in the territory.

The priority towards pollution reduction require first of all areas with high degree of contamination and higher population density. The fundamental difference is the product of these two parameters.

Reducing pollution in general can be achieved in different ways - change in the sector structure of the economy, introduction of innovative technologies, the use of industrial waste, 
construction of treatment facilities, carrying out a forestation and so on.

Typically, the implementation of such measures requires some investment costs. In terms of quantitative assessment of the effect of ecoinvestments requires identifying appropriate dependencies linking the size of investment with the value of the results obtained.

One way of such a dependence can be linear type functions such as:

$\Delta Z=b K$

where:

$$
\begin{aligned}
& K \text { - the volume of eco-investment, } \\
& b \text {-constant coefficient. }
\end{aligned}
$$

For typical projects the pollution reduction capital intensity is known and can be used for the purposes of economic analysis of investment options. In some cases, may also be involved and analyzed a combination of standard and custom project developments.

Towards the important areas of pollution reduction shall be included fixed assets rennovation, which, along with the savings of current production resources provides a better environment. A typical example to be considered is a renewal of vehicles that resulting in reduced fuel consumption per mile that accordingly reduces the amount of gas emissions.

Our studies revealed the quantitative regularities for the process of system update consistency of equipment in industrial plants, which can similarly be used to analyze the dynamics of pollution.

In particular, it should be considered a reasonable to use the following quantitative patterns:

$$
\Delta Z=\frac{z_{0}}{F_{0}} k_{\text {iH }} K,
$$

where:

$$
\begin{aligned}
& Z_{0}-\text { pollution emissions in the operation of } \\
& \text { machines in the base period. } \\
& F_{0} \text { - the original equipment cost, } \\
& k_{i H^{-}} \text {innovativity coefficient, based on } \\
& \text { pollution factor, }
\end{aligned}
$$

$$
K \text {-cost imposed by the new equipment }
$$

The analysis of the dependence shows that investments's eco-efficiency is determined primarily by the size of the ratio of pollution to the cost of fixed assets in the base period of operation.

Also significant value has the innovative new technology that characterizes the "jump" to reduce pollution when replacing existing technology innovation. I should add that this factor is determined by the parameters of existing and new technology.

In accordance with presented dependence more investments correspond to a current number of vehicles, which in turn intensifies the reduction of pollution.

However, it should be noted, that this directly proportional dependence occurs in the form of approximately stable volumes of production. If the dynamics of these volumes occurs, the indicated dependence shall be slightly adjusted.

Of course, the environmental effectiveness of a new technology depends on its technological purpose, the rate of technological progress, industry conditions and so on.

The variety of vehicles and assets raises the problem of determining the best areas of the ecoinvestments, and those investments that tangentially affect the state of pollution. Let's analyze a number of parameters of air pollution on the example of Poland - Voivodships. The table 1 indicates the relevant statistics for the period 2005-2012 year (CSO, 2013).

Overall, during the study period, pollution by dust has decreased by large size - about 2 times. At the same time gas pollution emissions decreased by $19 \%$. Significantly (by $45 \%$ ) were reduced the emissions of sulphur dioxide.

On the same level remained emissions of carbon dioxide and nitrogen oxides.

Taking into consideration the current trends, we can conclude that dust contamination is possible to reduce more rapidly, including through the use of appropriate technology filtering gas mixtures. 
Table 1. Emission and reduction of air pollutants in Poland 2005-2012

\begin{tabular}{|l|l|c|c|c|c|}
\hline & $\begin{array}{l}\text { Emission of pollutants } \\
\text { in th.tons }\end{array}$ & 2005 & 2010 & 2011 & 2012 \\
\hline 1 & Dust & 111 & 63 & 58 & 52 \\
\hline 2 & $\begin{array}{l}\text { Particulates from the } \\
\text { combusion of fuels }\end{array}$ & 89 & 45 & 40 & 37 \\
\hline 3 & $\begin{array}{l}\text { Cement and lime } \\
\text { particulates, fire- } \\
\text { resistant materials }\end{array}$ & 3 & 2 & 3 & 2 \\
\hline 4 & $\begin{array}{l}\text { Gases (excludiong } \\
\text { carbon dioxide) of } \\
\text { which }\end{array}$ & 2007 & 1704 & 1665 & 1627 \\
\hline 4.1 & Sulphur-dioxide & 856 & 519 & 503 & 469 \\
\hline 4.2 & Carbon-oxide & 326 & 344 & 341 & 334 \\
\hline 4.3 & Nitrogen-oxides & 351 & 341 & 332 & 316 \\
\hline
\end{tabular}

Using the raw data, we develop such quantities as population density, the ratio of its size to the size of the residence surface area and the average concentration of pollution - emissions related to the size of the territory they pollute.

Taking into consideration obtained data under the proposed approach we shall multiply the results and thus will determine the Voivodeship rating factor on the priority pollution reduction.

The relevant statistics on plant equipment that ensures the reduction of air pollution in Poland in 2012 is shown in Table 2 (CSO, 2013).

Table 2. Basic air pollution reduction systems in plants 2012

\begin{tabular}{|c|l|c|c|c|c|}
\hline \multirow{2}{*}{ Equipment } & \multicolumn{4}{c|}{ Equipment efficiency } \\
\cline { 2 - 6 } & total & low & moderate & high \\
\hline 1. & Cyclones & 3255 & 478 & 878 & 1899 \\
\hline 2. & Multicyclones & 965 & 141 & 260 & 564 \\
\hline 3. & Fabric filters & 5500 & 581 & 1259 & 3660 \\
\hline 4. & Electrofilters & 577 & 35 & 91 & 451 \\
\hline 5. & $\begin{array}{l}\text { Wet air } \\
\text { cleaners }\end{array}$ & 1168 & 459 & 296 & 413 \\
\hline
\end{tabular}

For some types of equipment, there are three levels of performance: low, medium and high.
Obviously there is a difference in the cost of the equipment, which makes specific factory rational choice alternative treatment. In some cases improve treating achieved by means of multiple staging of this process. For example, two stages option purification takes place the following quantitative relation:

$$
U=U_{1}+\left(1-U_{1}\right) \cdot U_{2},
$$

where:

$$
\begin{aligned}
& U \text { - share of "hard" phase mixture shown } \\
& \text { cleaning system in relation to the } \\
& \text { amount of "hard" phase input, } \\
& U_{1} \text { - share of "hard" phase, which remains } \\
& \text { after the first stage of filtration. } \\
& U_{2} \text { - fraction of the solid phase, which } \\
& \text { remains after the second stage of } \\
& \text { filtration. }
\end{aligned}
$$

If we consider the value of entered indicators as filtration efficiency, the overall efficiency in some way connected with the relevant local efficiency. If for example we assume that $U_{1}=U_{2}=0.8$, then the resulting efficiency is equal to $U=0.96$. That is already a two stage filtration that provides a significant effective performance compared with similar local efficiency.

The economic problem here is that increasing stages of filtering significantly increases the cost of the equipment, while increasing efficiency to a lesser extent.

This is an important law, since there is a need to correlate the cost of the equipment with its performance.

Let's take a regional interpretation of equation (4) as an example the emission of dust pollution on the territory of Poland Voivodships. Relevant primary statistics are given below in Table. 3 (Voytsekhovska V. , 2011).

The statistical data are further used to determine for each of the Voivodships concentration of gas emissions and population density in the area. The product of these indicators can serve as a measure of pollution's reduction efficiency (rate).

The results of the corresponding calculations are presented in Table 4 (CSO, 2013). 
Table 3. The statistical data concerning population parameters, area and amount of dust pollutants emission, Polish Voivodeships, 2012

\begin{tabular}{|c|c|c|c|c|}
\hline & Voivodships & 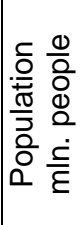 & 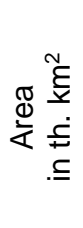 & 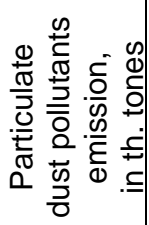 \\
\hline 1 & Lower Silesian & 2.9 & 19.9 & 4. 0 \\
\hline 2 & Kuyavian-Pomeranian & 2.1 & 18.0 & 3.9 \\
\hline 3 & Lublin & 2.2 & 25.1 & 2.1 \\
\hline 4 & Lubusz & 1.0 & 14.0 & 1.2 \\
\hline 5 & Łódź & 2.5 & 18.2 & 3.4 \\
\hline 6 & Lesser Poland & 3.3 & 15.2 & 3.9 \\
\hline 7 & Masovian & 5.3 & 35.5 & 4.6 \\
\hline 8 & Opole & 1.0 & 9.4 & 1.2 \\
\hline 9 & Subcarpathian & 2.1 & 17.8 & 1.7 \\
\hline 10 & Podlaskie & 1.2 & 20.2 & 0.9 \\
\hline 11 & Pomeranian & 2.3 & 18.3 & 2.8 \\
\hline 12 & Silesian & 4.6 & 12.3 & 10.6 \\
\hline 13 & Świętokrzyskie & 1.3 & 11.7 & 2.7 \\
\hline 14 & Warmian-Masurian & 1.4 & 24.2 & 1.2 \\
\hline 15 & Greater Poland & 3.5 & 29.8 & 4.0 \\
\hline 16 & West Pomeranian & 1.7 & 22.9 & 2.6 \\
\hline
\end{tabular}

The comparison of ratings is showing, that the top three priority on reducing pollution include the following Provinces: Silesian, Lesser Poland, Lower Silesian.

The results are conditioned by the fact that in these Voivodships is the largest concentration of pollution and population density living in these areas.

The reason for it should be considered as the presence of large scale industrial production, which requires the involvement of a significant number of employees and activities which are based on industry specifics, that are related to pollution.

Priority means that first of all shall be implemented the environmental initiatives in these areas.
Table 4. The definition of Voivodeship rating for reducing dust pollution

\begin{tabular}{|c|c|c|c|c|c|}
\hline $\mathrm{Nr}$ & Voivodships & 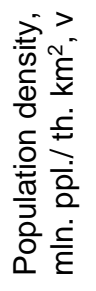 & 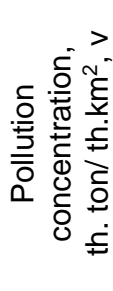 & 훙 흉 & 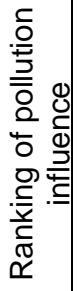 \\
\hline 1 & Lower Silesian & 0.15 & 0.20 & 3.0 & 3 \\
\hline 2 & $\begin{array}{l}\text { Kuyavian- } \\
\text { Pomeranian }\end{array}$ & 0.12 & 0.22 & 2.6 & 5 \\
\hline 3 & Lublin & 0.09 & 0.08 & 0.7 & 13 \\
\hline 4 & Lubusz & 0.07 & 0.09 & 0.6 & 14 \\
\hline 5 & Łódź & 0.14 & 0.19 & 2.7 & 4 \\
\hline 6 & Lesser Poland & 0.22 & 0.26 & 5.7 & 2 \\
\hline 7 & Masovian & 0.15 & 0.13 & 2.0 & 7 \\
\hline 8 & Opole & 0.11 & 0.13 & 1.4 & 10 \\
\hline 9 & Subcarpathian & 0.12 & 0.10 & 1.2 & 11 \\
\hline 10 & Podlaskie & 0.06 & 0.04 & 0.2 & 16 \\
\hline 11 & Pomeranian & 0.13 & 0.15 & 1.9 & 8 \\
\hline 12 & Silesian & 0.37 & 0.86 & 11.8 & 1 \\
\hline 13 & Świętokrzyskie & 0.11 & 0.23 & 2.5 & 6 \\
\hline 14 & $\begin{array}{l}\text { Warmian- } \\
\text { Masurian }\end{array}$ & 0.06 & 0.05 & 0.3 & 15 \\
\hline 15 & Greater Poland & 0.12 & 0.13 & 1.6 & 9 \\
\hline 16 & $\begin{array}{l}\text { West } \\
\text { Pomeranian }\end{array}$ & 0.07 & 0.11 & 0.8 & 12 \\
\hline
\end{tabular}

But the choices of eco-investments significantly affects the readiness of technical and technological solutions. Also important factors include absolute and specific costs, including such factors as capital intensity reduction of pollution (Voytsekhovskyy, Voytsekhovska, \& Symak, 2012).

As was previously analyzed from the two areas of air quality improvement for dust pollution better results are achieved, which decreased more rapidly.

A priori, this can be explained by the fact that there are appropriate technical solutions that do not require for their implementation major capital expenditures. At the same time, the chemical nature of pollution may require more complex 
development projects and significant capital investment.

Do not forget about the diversification aspects of environmental activities. In the majority of casses, the environmental measures of Voivodships are carried out independently at their own expense and opportunities. A compromise between the interests of the community as a whole and the community in some areas can be achieved through the introduction of appropriate criteria and constraints. Some approaches in this direction, were considered in (Voytsekhovska V. , 2011) (Voytsekhovska V. , 2012).

\section{CONCLUSIONS}

The performed studies have shown that the choice of parameters quantifying environmental assessment must take into account the impact of pollution from the beginning of the livelihoods of one man, and then summarize the number of residents living in a particular area
When it comes to air pollution, the output parameters should be considered a harmful gas in the air, the component that is correlated with the amount of gas emissions per unit of area. For residents of the entire territory of the overall pollution impact is considered additive that is proportional to the population

The statistical analysis of Polish Voivodeships illustrates, that these indicators and their product significantly differ for different areas. Because of this latter figure may be used to identify priority areas for the implementation of measures to reduce pollution. Selecting appropriate investment projects requires further assessment of the eco-costs effectiveness, which is largely dependent on the degree of innovation of new technology. The strategy to reduce pollution at the country level should be consistent with the eco-activities for individual Voivodeships considering the level of local pollution, their industrial specific as well as general and local resource capacity allocation formation and implementation of eco-investment projects.

\section{WORKS CITED}

CSO. (2013). Environment - 2013 report. Warsaw, 2013: Central Statistical Office.

EEA. (2013). Air Quality in Europe - 2013 report. 112. Luxemburg: European Environment Agency, 2013/European Commission Edition.

U.N. (2008, 12 9). Doha Declaration on Financing for Development: outcome document of the Followup International Conference on Financing for Development to Review the Implementation of Monterrey Consensus. Follow-up International Conference in Financing for Development to review the implementation of 2. Monterrey Consesnsus, 24. Doha, Quatar: United Nations publications/A/CONF.212/L.1/Rev.1.

U.N. (2012). The future we want. Resolution adopted on the United Nations General Assembly on 27 July 2012, 53. United Nations General Assembly/A/RES/66/288/United Nations.

Voytsekhovska, V. $(2011,05)$. Economic-statistical analysis and optimization of regional innovative development. International Journal of Arts and Sciences, Business and economics, 4(20), 4349.

Voytsekhovska, V. (2012). Economic-Statistical analysis of regional development and environmental investments diversification. Information technologies, economics and law, current trends and perspective development (ITEP- 2012) - Part I (pp. 142-143). Chernivtzi, Ukraine: Bukovina University, .

Voytsekhovskyy, V., Voytsekhovska, V., \& Symak, A. (2012). Economic-Statistical analysis of regional development and environmental investments diversification. Management 2012 - Abstract Proceedings (pp. 147-152). Belgrade: Faculty of Business and Industrial Management. Union University. 
Received for publication:

26.08.2014

Accepted for publication:

27.12.2014

\section{How to cite this article?}

Style - APA Sixth Edition:

Voytsekhovskyy, V., \& Voytsekhovska, V. (2015, Jan 15). Methodological aspects of quantitative assessment of the pollution reduction - Status and trend -. (Z. Čekerevac, Ed.) MEST Journal, 3(1), 163-169. doi:10.12709/mest.03.03.01.17

Style - Chicago Fifteenth Edition:

Voytsekhovskyy, Viktor, and Viktoriya Voytsekhovska. 2015. "Methodological aspects of quantitative assessment of the pollution reduction - Status and trend -." Edited by Zoran Čekerevac. MEST Journal (MESTE) 3 (1): 163-169. doi:10.12709/mest.03.03.01.17.

Style - GOST Name Sort:

Voytsekhovskyy Viktor and Voytsekhovska Viktoriya Methodological aspects of quantitative assessment of the pollution reduction - Status and trend - [Journal] // MEST Journal / ed. Čekerevac Zoran. - Belgrade : MESTE, Jan 15, 2015. - 1 : Vol. 3. - pp. 163-169.

Style - Harvard Anglia:

Voytsekhovskyy, V. \& Voytsekhovska, V., 2015. Methodological aspects of quantitative assessment of the pollution reduction - Status and trend -. MEST Journal, 15 Jan, 3(1), pp. 163-169.

Style - ISO 690 Numerical Reference:

Methodological aspects of quantitative assessment of the pollution reduction - Status and trend -. Voytsekhovskyy, Viktor and Voytsekhovska, Viktoriya. [ed.] Zoran Čekerevac. 1, Belgrade : MESTE, Jan 15, 2015, MEST Journal, Vol. 3, pp. 163-169. 